\title{
ELK ASIA PACIFIC JOURNAL OF SOCIAL SCIENCE
}

ISSN 2394-9392 (Online); DOI: 10.16962/EAPJSS/issn. 2394-9392/2015; Volume 5 Issue 1 (2018)

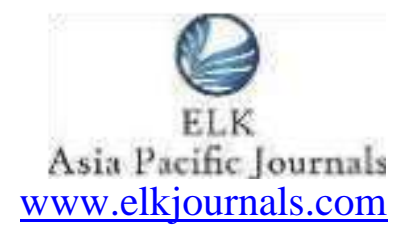

\section{SINO-INDIAN GEOSTRATEGIC COMPETITION: BANGLADESH PERSPECTIVE}

\author{
Taufiq -E- Faruque \\ University of Dhaka, Bangladesh \\ tefdrmc@gmail.com
}

\begin{abstract}
The simultaneous rise of China and India has been creating significant transformation in the international power hierarchy. At the same time, their neighbouring countries are becoming hot spots for a power struggle between them. Bangladesh is proximate to both India and China, and also has access to the Indian Ocean through the Bay of Bengal. Due to this unique geographic location of Bangladesh, both India and China are competing for better ties with the country. Following a qualitative approach, the paper aims to the explain the reasons behind this growing Sino-Indian competition over Bangladesh from a geostrategic point of view. It further tries to draw a Bangladeshi perspective on the Sino-Indian competition considering both internal and external dynamics. This study will be significant to understand the foreign policy determinants of Bangladesh with respect to its cooperation with India and China.
\end{abstract}

Keywords: Bangladesh, China, Geostrategy, India, South Asia

\section{INTRODUCTION}

Bangladesh has received a significant amount of investments and economic assistance from China and India in recent years. The two Asian powers are in a "geopolitical tug of war" to engage them in Bangladesh's manufacturing, infrastructure, energy and defence sectors at impressive margins (Cookson and Joehnk, 2018). The inevitable question is why the world's second and sixth largest economies respectively are cosying up to the world's 43rd largest economy? Why India and China are competing for better ties with Bangladesh? What are the implications for Bangladesh?

India played a pivotal role in the emergence of Bangladesh as an independent nation in 1971. As a result, Bangladesh became a natural ally of India. But the relationship between the two countries faced difficulties due to India's lack of foresight and petty-minded handling of bilateral issues (Datta, 2008). 


\section{ELK ASIA PACIFIC JOURNAL OF SOCIAL SCIENCE}

ISSN 2394-9392 (Online); DOI: 10.16962/EAPJSS/issn. 2394-9392/2015; Volume 5 Issue 1 (2018)

China, using its economic clout, has successfully created considerable inroads to India's neighbouring countries, including Bangladesh, over the past decades. Recently, India has been trying to restructure its relations with neighbouring countries in order to halt China's growing presence in South Asia and the Indian Ocean region. India and China are simultaneously trying to climb up in the global power hierarchy with their economic growth. But for the first instance, they are competing for the PanAsian leadership (Schmidt,2011). Thus, the persistent competition between India and China over Bangladesh can be considered as a part of a much wider rift between the two countries (Hossain, 2016).

This paper aims to explain the underlying causes behind Sino-Indian competition over Bangladesh from a geostrategic point of view. It shows how Indian and Chinese geostrategic calculations in region intersect each other in Bangladesh. Given the changing dynamics within the region and beyond, this geostrategic tug of war between India and China can bring farreaching implications in Bangladesh's politics, economy, and foreign relations. Thus, the paper further aims to analyze the
Bangladeshi perspective on the problem under study, keeping the country's domestic politics and regional landscape into consideration.

The paper is organized into seven sections. After the introduction, the next section tries to conceptualize geostrategy as a foreign policy approach. The third section puts the geostrategic importance of Bangladesh from both Indian and Chinese point of view within a historical framework. Taking Bangladesh's geostrategic significance into consideration, the fourth and fifth sections explains the recent developments on Dhaka's relations with New Delhi and Beijing respectively. The following section analyzes the challenges and prospects for Bangladesh to illustrate the implications for Bangladesh on the issue under study. The last section offers conclusions.

\section{LITERATURE REVIEW}

Due to its territorial size, economic might, and historical legacy India enjoys significant influence over the small countries across South Asia. However, China has managed to secure a significant presence in countries that were considered as within India's zone of influence in the 


\section{ELK ASIA PACIFIC JOURNAL OF SOCIAL SCIENCE}

ISSN 2394-9392 (Online); DOI: 10.16962/EAPJSS/issn. 2394-9392/2015; Volume 5 Issue 1 (2018)

region through its policy of noninterference and economy-driven foreign policy (Datta, 2008). Unlike India, China does not enjoy any historic-cultural linkages with Bangladesh. But Beijing has successfully established comprehensive relations with Dhaka by neutralizing New Delhi's influence through its massive economic clout, rising status in the global power hierarchy, and military cooperation (Datta, 2008). There are some inbuilt advantages for China while interacting with Bangladesh. The absence of geography-related bilateral tensions and a prolonged policy of non-interference in the domestic matters have created a widespread support base for China Bangladeshis. Therefore, all the Bangladeshi political blocs consider closer ties with Beijing as an option to gain political capital. On the other hand, Bangladesh's encounter with India has been always associated with geographydriven disputes (e.g. sharing of transboundary river water, land boundary issues), political controversies, and most importantly security concerns form both sides (Datta, 2008; Wagner, 2016).

China's economy-driven foreign policy and strategic partnerships with India's neighbouring states have the potential to reshape the geopolitical alignment in South Asia and, therefore, is a significant challenge for India's own global ambitions. The Indian leadership should "manage not only its immediate neighbourhood with greater strategic vision but also monitor China's growing clout" at the regional level (Pant, 2018).

\section{METHODOLOGY}

The paper falls under qualitative analysis. It takes data from secondary (e.g. government institutes, newspapers, thinktank organizations, relevant peer-reviewed journals) sources. Numeric evidence, quantitative data representations are also incorporated in the forms of generalized sentences to achieve some tangible output of the study.

\section{CONCEPTUALIZING \\ GEOSTRATEGY}

There is no consensus among the academics, theorists, and practitioners about the definition of "geostrategy". In general terms, Geo-strategy refers to a particular approach to foreign policy which merges strategic consideration with geopolitical ones (Brzezinski, 1986). Like 


\section{ELK ASIA PACIFIC JOURNAL OF SOCIAL SCIENCE}

ISSN 2394-9392 (Online); DOI: 10.16962/EAPJSS/issn. 2394-9392/2015; Volume 5 Issue 1 (2018)

all strategies, geostrategy means the use of means (e.g. a country's resources) to achieve ends having geographical significance (e.g. securing access to certain trade routes, rivers, islands and seas).

According to Jakub J. Grygiel (2006),

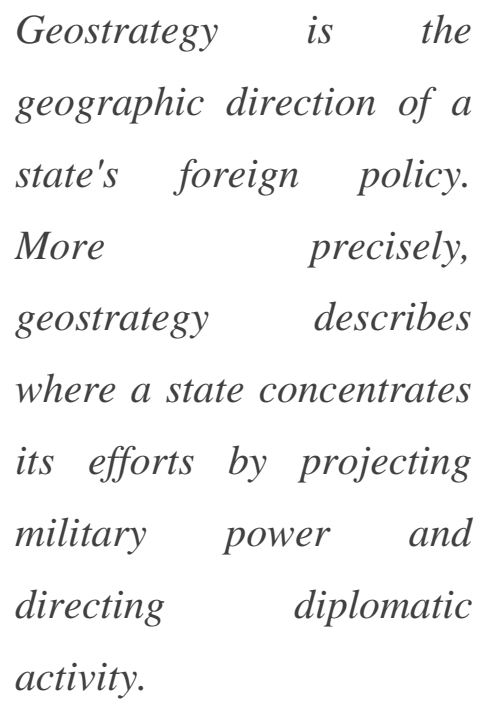

The geostrategic importance of a country or a region is not constant, therefore, it can rise with the changing characteristics of its elements. As a result, it is necessary to study a country's geo-strategic value both from the global and regional perspective. In contemporary international relations, a country's "geostrategy" refers to the combined factors related to its strategic goals and geographic considerations (Jiemian, 2014). The outcome of geostrategic competitions between different countries is often determined by their economic, military, and diplomatic capability within the global order.

\section{GEOSTRATEGIC SIGNIFICANCE OF BANGLADESH: AN OVERVIEW}

The area that now forms the state of Bangladesh has a long history of geostrategic significance. Due to its fertile landmass, Bengal, more specifically its Bhati region which covers most of the part of Bangladesh, served as the economic powerhouse of the Mughal Empire, the empire that possessed one-fourth of the world's GDP till the end of the 17th century (Eaton, 1996). Ports along the rivers of Bengal, and Chittagong on the Bay of Bengal facilitated regional and trans-regional maritime trade of jute, textiles, sugar, indigo, tea, opium and spices to Persia, Middle East, and as far as European ports. But the hundreds of years of colonial subjugation exploited the indigenous industries across the region. Moreover, the eastern part of Bengal, that later became Bangladesh, became increasingly marginalized and was affected by successive natural disasters and famines. However, becoming the eastern wing of Pakistan in 1947 did not bring any considerable economic development of the region. The profits from the exports of East 


\section{ELK ASIA PACIFIC JOURNAL OF SOCIAL SCIENCE}

ISSN 2394-9392 (Online); DOI: 10.16962/EAPJSS/issn. 2394-9392/2015; Volume 5 Issue 1 (2018)

Pakistan were mostly invested in West Pakistan's industries and infrastructural projects (Andersen, 2012).

Following the war of independence in 1971, it took more than two decades to bring about political stability and foster economic growth. The country's GDP growth rate has been within the range of 6-7 $\%$ since the past decade and a half. Its total size of GDP has more than doubled in the last one and a half decade. According to a Goldman-Sachs report of 2012, Bangladesh is among the "Next Eleven", countries that have a high potential of becoming the world's largest economies in within this century. The country has the third largest Muslim population in the world, following to a tolerant and inclusive Sufi school of thought. Moreover, due to the mostly homogenous population, there is no largescale inter-ethnic conflict in Bangladesh, unlike most of the states in this region. Bangladesh has improved significantly in several indicators like education, healthcare, and child mortality rate. Therefore, Bangladesh, having a huge youth workforce aged between 15-30 years, is now on a position to reclaim its historic geostrategic importance and, thereby, act as the commercial hub of this densely rapidly growing region. Any discussion about a country's geostrategic importance inevitably focuses on its geographical location. India is the primary neighbour of Bangladesh, surrounding it by almost three sides. The two countries share a 4096kilometre border, the fifth-longest land border in the world. Bangladesh also shares a 271-kilometre long, relatively small but significant, frontier with Myanmar in its south-eastern part. The Bay of Bengal, with shared coastline with India and Myanmar, makes up its southern frontier. A roughly 20-mile wide Indian territory separates Bangladesh's northern border from the two landlocked Himalayan states- Nepal and Bhutan. Moreover, China's southern border is roughly 100miles away from the northwest frontier of Bangladesh.

Geographically surrounds Bangladesh on three sides. But Bangladesh also almost separates northeastern India from its mainland. A roughly 12-mile wide strip, known as Shiliguri corridor, is the only land route between India and its resourcerich but least developed seven northeastern states. Thus, India needs transport access through Bangladesh to integrate its northeastern region to its mainstream economy. 


\section{ELK ASIA PACIFIC JOURNAL OF SOCIAL SCIENCE}

ISSN 2394-9392 (Online); DOI: 10.16962/EAPJSS/issn. 2394-9392/2015; Volume 5 Issue 1 (2018)

According to Mantoo (2013):

The unique geographic
location of Bangladesh
which cuts the troubled
North East region of India
off from mainland
constitutes a significant
security weak point for
India for the fact that the
region shares a border
with China and that
various insurgent groups
are active within the
region that is fighting
against the Indian
government for self-
determination.

As Bangladesh stretches between the Himalayan foothills in the north and the Bay of Bengal in the south, it is the only geographical real-estate to connect South Asia with South East Asia. Therefore, the country is at the centre of three rapidly growing economic regions of the world: China in the north, India's mainland in the west, and South East Asia to the east. This unique geostrategic location gives Bangladesh the opportunity to play the central role in any future trans-regional economic initiative. Nevertheless, the Bay of Bengal is the nearest option to get sea access for virtually landlocked China's Southern provinces, Nepal, Bhutan, and India's seven northeastern states. Thus Bangladesh has the potential to provide deep sea-port facility to the entire region. According to Yusuf (2014): 


\section{ELK ASIA PACIFIC JOURNAL OF SOCIAL SCIENCE}

ISSN 2394-9392 (Online); DOI: 10.16962/EAPJSS/issn. 2394-9392/2015; Volume 5 Issue 1 (2018)

Bangladesh's proximity to India, relatively cheap work-force, and access to the Bay of Bengal have considerable implication for China's geostrategic calculation on South Asia and the Indian Ocean region. Nadim Mahmud (2018), a PhD scholar at Zhongnan University of Economics and Law in China believes that "India factor" is one of the main reason behind Bangladesh becoming an important country for China. He said, "China aims to break India's absolute role upon its neighbours and that boosts the strategic importance of Bangladesh."

More than $80 \%$ of China's energy import from the Persian Gulf states are transported through the Strait of Malacca, a narrow stretch of water connecting the Indian Ocean and the Pacific Ocean. But the Straits of Malacca is considered as vulnerable because India, in a potential war situation, has the capacity to block it through its naval facilities stationed at the Andaman Islands. Therefore, land-based connectivity with Bangladesh is crucial for China in order to develop oil and gas pipelines from the Chittagong port to Kunming through Myanmar's territory. As a result, China could secure easy and cheap transportation of the imported energy resources in the virtually landlocked provinces of southern-western China. Moreover, by doing so China could reduce its over-dependence on the Straits of Malacca. Moreover, to further expand its market it this densely populated region China needs mechanisms under regional connectivity. But large-scale economic connectivity with India's northeastern region is not likely through the McMahon line, a deputed borderline between Tibetan region of China and northeast India. The only feasible way to get access to Indian vast market is through Bangladesh. To operationalize the proposed Bangladesh- China-IndiaMyanmar (BCIM) economic corridor, it is necessary for China to invest in infrastructural development in Bangladesh (Nahreen, 2017).

However, the future trade relations with Bangladesh will determine which Asian power will enjoy greater influence in the country. China, due to its bigger economy vis-à-vis India, is in an advantageous position in terms of trade and investment. If China further opens-up its market for Bangladeshi products, there might be a shift in the balance of power in Bangladesh (Cookson and Joehnk, 2018). 


\section{ELK ASIA PACIFIC JOURNAL OF SOCIAL SCIENCE}

ISSN 2394-9392 (Online); DOI: 10.16962/EAPJSS/issn. 2394-9392/2015; Volume 5 Issue 1 (2018)

\section{INDIA'S "NEIGHBORHOOD FIRST DIPLOMACY" IN BANGLADESH}

The bilateral relations between India and Bangladeshis fairly in a good place today since the Awami League-led government came into power since 2009. One major agenda that has brought the two governments close has been counterterrorism, both the states are committed to combat terrorism at the region and are not afraid to crack down hard on militant groups (Kugelman, 2018).

Prime Minister Sheikh Hasina clearly subscribed to an India friendly policy and extended security cooperation with New Delhi (Rahman, 2016). During Sheikh Hasina's visit to New Delhi on January 2010. Both sides signed an a51-point joint agreement including security cooperation, development assistance, and energy imports. In September 2011 the then Indian Prime Minister Manmohan Singh came to Dhaka. During that visit, a protocol to the 1974 Land Boundary agreement was signed, providing a settlement to the boundary disputes. Although, the most anticipated agreement on the sharing of Teesta river water could not be signed during that visit. The dispute over the maritime border between the two countries was resolved in 2009 through the International Tribunal for the Law of the Sea, in which Bangladesh secured control over $80 \%$ of the disputed maritime area.

The two country's bilateral relations further developed since Bharatiya Janata Party (BJP)-led alliance came into power in India in 2014. Prime Minister Narendra Modi made his first visit to Dhaka in June 2015. Several agreements were signed between the two sides including power export to Bangladesh, India's usage of Bangladeshi sea-ports, Bangladesh's export of internet bandwidth in India's northeast, bus routes across the border, and a swap of the disputed enclaves. India agreed to provide US $\$ 2$ billion line of credit to Bangladesh for the use of infrastructural projects. These developments were considered as a manifestation of the Narendra Modi government's "neighbourhood first" policy, which can be considered as the Indian version of the Monroe Doctrine. At the same time, Dhaka has provided strong support to New Delhi in the regional politics. In 2016, India managed to get support from several South Asian countries, including Bangladesh, to boycott the annual South Asian Association for 


\section{ELK ASIA PACIFIC JOURNAL OF SOCIAL SCIENCE}

ISSN 2394-9392 (Online); DOI: 10.16962/EAPJSS/issn. 2394-9392/2015; Volume 5 Issue 1 (2018)

Regional Cooperation (SAARC) summit scheduled to be held in Islamabad. As a result, Pakistan failed to host the most prestigious regional event. Thus, Dhaka provided support in the diplomatic front on New Delhi's attempt to regionally isolate Pakistan over its alleged support to terrorist groups operating inside Indian state of Jammu and Kashmir ("Bangladesh boycotts SAARC summit amid IndiaPakistan row", 2016).

During Prime Minister Sheikh Hasina's visit to New Delhi in November 2017, Indian companies signed investment deals worth of US\$9 billion with their Bangladeshi counterparts. Bangladesh has also agreed to set up special economic zones in designated locations across the country for Indian investors, according to a joint statement issued by both the countries (“Indian businesses to invest $\$ 9$ billion", 2017). Harsh Vardhan Shringla, the Indian high commissioner to Bangladesh, said India is keen to further invest Bangladesh's power, liquefied natural gas and port sectors due to great business potentials ("India plans to invest \$3b in Bangladesh", 2017). During Prime Minister Sheikh Hasina's visit to New Delhi in May 2018, India signed two major defence pacts with
Bangladesh. These agreements include extending defence cooperation, arrangements of regular joint-exercise between armed forces, and a US\$500 million worth soft loan to Bangladesh for buying Indian military hardware ("Defense Cooperation: Dhaka, Delhi sign deal", 2018). For the first time, India reached to make such agreements with any of its neighbours in South Asia.

India's main influence over Bangladesh is in the area of trade and economic activities. As a result, Bangladesh suffers a huge trade deficit with its primary neighbour. After the end of the cold war in the early 1990s, India further liberalized its economy to expand its market abroad. Since then her exports to Bangladesh increased significantly. Currently, Bangladesh is the ninth largest importer of Indian goods ("India's exports to Bangladesh bounce back", 2017). According to India's Commerce Ministry, Bangladesh imported US $\$ 6.8$ billion worth of goods in the 2017-18 fiscal year, increasing the figure by record $13 \%$. On the other hand, Bangladesh's Export Promotion Bureau stated that the country's exports to India stood at only US $\$ 154.88$ million in the first quarter (July- 


\section{ELK ASIA PACIFIC JOURNAL OF SOCIAL SCIENCE}

ISSN 2394-9392 (Online); DOI: 10.16962/EAPJSS/issn. 2394-9392/2015; Volume 5 Issue 1 (2018)

September) of the 2018-19 fiscal year. India is the second largest sources of raw materials for Bangladeshi manufacturing industries, which resulted in the import surge. On the other hand, Bangladeshi export products are denied access to the Indian market due to several non-tariff barriers (Rashid, 2011). Moreover, informal trade is also in India's favour by a large margin due to remittances for Indians working in the country. Bangladesh also contributes to Indian tourism and health industry by contributing a significant number of tourist and patients annually. However, recent developments suggest that India-Bangladesh economic relations have been growing at a rapid pace. Currently, Bangladesh is the largest trading partner of India in South Asia. India provided its largest ever US $\$ 4.5$ billion loan Bangladesh during the Indian Finance Minister Arun Jaitley visit to Dhaka on October 2017. The Indian media reported this move as a manifestation of India's greater strategic plan to wean Bangladesh away from Chinese investments ("India extends \$4.5 billion in loans to Bangladesh”, 2017).

Despite growing warm relationship between India and Bangladesh, the long- standing agreement on the sharing of waters of the Teesta river has not yet signed. Moreover, waters of more than 50 rivers come to Bangladesh through India. Thus, the future of transboundary water sharing will be a significant factor in the relationship between the two countries in the upcoming days.

\section{CHINA'S "BELT AND ROAD DIPLOMACY" IN BANGLADESH}

The bilateral relations between Bangladesh and China has deepened significantly since 2009. A number of high-level state visits have taken place from both sides. Bangladesh officially agreed to join the China-led Belt and Road initiate, also known as OBOR initiative, during Prime Minister Sheikh Hasina's visit to Beijing in June 2014. China agreed to provide assistance for five more projects at a total cost of US\$5 billion during the visit ("China visit to deepen relation: PM", 2014).

China Major Bridge Engineering Company Ltd, a state-owned company, was selected to construct the US\$ 2.9 billion Padma Multipurpose Bridge after the World Bank halted its fund oven raising graft allegations in 2012. The company has been 


\section{ELK ASIA PACIFIC JOURNAL OF SOCIAL SCIENCE}

ISSN 2394-9392 (Online); DOI: 10.16962/EAPJSS/issn. 2394-9392/2015; Volume 5 Issue 1 (2018)

investing US\$ 2 billion or more than $70 \%$ in the project, Bangladesh's largest infrastructure to date ("Chinese company to construct the Padma bridge”, 2014).

Chinese President Xi Jinping visited Dhaka on October 2016, the first time by a Chinese President in more than 30 years. Both sides signed 27 deals, related to 15 agreements and Memorandum of Understandings and 12 loan and mutual cooperation agreements. These developments were considered as a "geopolitical game changer" in South Asia and the Indian Ocean region. The Bangladesh-China bilateral relations evolved to "Strategic Partnership of Cooperation" from "Comprehensive Partnership" since then (Nahreen, 2017).

A Chinese consortium, comprising of the Shanghai Stock Exchange (SSE) and the Shenzhen Stock Exchange (SZSE), has bought a 25\% share of the Dhaka Stock Exchange (DSE), Bangladesh's largest stock market, in May 2018. The Chinese consortium snatched this share after outbidding the attempt by the National Stock Exchange (NSE) of India. This suggests that the Sino-Indian competitions over securing a strategic presence in
Bangladesh is getting a zero-sum nature, and China is securing the positive outcome due to its economic advantage in the most situation. With its successful penetration in Bangladesh's stock market, China seems to be even more influential in the country (Kabir, 2018).

Since 2006 China has been Bangladesh's largest trading partner, replacing India. According to Bangladesh Bank, Bangladesh imported UD\$24.66 billion worth of goods in the first half of the 201718 fiscal year. At the same time, China is shifting its economy from low-tech manufacturing industries to high-tech industries. As a result, countries like Bangladesh will have the potential opportunity to export their manufactured products in Chinese markets in near future at a larger scale. Statistics are suggesting that Bangladesh's export to China has increased significantly over the last few years. As Bangladesh Export Promotion Bureau suggests, the country's export to China increased by $17.49 \%$ to US\$949.41 million in 2016-17 fiscal year from the US $\$ 808.14$ million in the 2015-16 fiscal year. Bangladesh Bank recently allowed other banks to open foreign currency clearing account with the central bank in Chinese 


\section{ELK ASIA PACIFIC JOURNAL OF SOCIAL SCIENCE}

ISSN 2394-9392 (Online); DOI: 10.16962/EAPJSS/issn. 2394-9392/2015; Volume 5 Issue 1 (2018)

yuan (Renminbi). It is assumed that this decision by the central bank will further give a boost to the bilateral trade between the China and Bangladesh ("Bangladesh Bank allows forex clearing account in yuan”, 2018).

At present, China's foreign assistance to Bangladesh amounts to about US\$1 billion a year (Cookson and Joehnk, 2018). Moreover, Bangladesh is supposed to receive $\$ 24.45$ billion in the form of bilateral assistance and a further $\$ 13.6$ billion investment from China for several mega-projects across the country as promised by China's President Xi Jinping during his visit to Dhaka back in October 2016. Thus, the sum total of US $\$ 38.05$ billion has become the biggest ever assistance to Bangladesh promised by any country. Days ahead of President Xi Jinping's arrival in Dhaka, the then Chinese Ambassador Ma Mingqiang said in a seminar that China aims to become the number one investor in Bangladesh ("China to be a top investor in Bangladesh", 2016). Most of these Chinese investments are focused on connectivity, seaports, energy, infrastructure, and manufacturing sectors.
Bangladesh has a long history of buying Chinese military hardware. The ChinaBangladesh Defense Cooperation Agreement was signed in 2002. Since then China has been the main supplier of weapons to the Bangladesh armed forces. According to a report by Stockholm International Peace Research Institute 19\% of China's arms supplies went to Bangladesh between 2013 and 2017, making Bangladesh the second largest buyer of Chinese military hardware worldwide after Pakistan. Bangladesh acquired two Ming-class submarines from China for \$203 million in 2017, which created heated debate among Indian security observers. Meanwhile, India has been trying to break the Chinese monopoly in Bangladesh's defence market (Cookson and Joehnk, 2018).

China is also trying to make a significant presence in Bangladesh in the cultural. Confucius Institute and other cultural platforms have been established in many Bangladeshi universities, subsidized by the Chinese government. Moreover, every year a good number of Bangladeshi students have been going to Chinese universities to pursue their higher studies and exchange programs. The emerging Bangladesh- 


\section{ELK ASIA PACIFIC JOURNAL OF SOCIAL SCIENCE}

ISSN 2394-9392 (Online); DOI: 10.16962/EAPJSS/issn. 2394-9392/2015; Volume 5 Issue 1 (2018)

China axis has started to draw attention in different quarters both at the regional and global level. Experts have argued that Bangladesh has been trying to maintain a delicate balance between its relations with China and India at the regional level. But on the other hand, Bangladesh has "downplayed" its existing strategic partnership with the United States in an attempt to solidify its relationship with China (Yasmin, 2016).

\section{CHALLENGES AND PROSPECTS} FOR BANGLADESH AMIDST SINOINDIAN GEOSTRATEGIC

\section{COMPETITION}

The current Sino-Indian competition over their strategic presence in Bangladesh illustrates the significance of Bangladesh's location in South Asia forms a geostrategic point of view. It is likely that China and India will further compete to edge each other out in their battle for influence and will, therefore, try to materialize their respective geostrategic calculations in the region. An old African proverb says, "when elephants fight, it's the grass that suffers". Therefore, economically weak countries in the region like Bangladesh are in a danger of becoming passive victims of this growing competition between the two rapidly developing Asian powers.

Vice Chancellor of India's Rabindra Bharati University, Professor Sabyasachi Basu Roy Chaudhury (2017) said that China has now become "thorn" in the relations between India and Bangladesh. The renowned Indian intellectual elaborated his point by emphasizing on China's huge investment Bangladesh and Bangladesh's participation in the China-led OBOR initiative, a project that India's considers as controversial (Imam, 2017). This highly unconventional, if not a politically unethical, statement by an academic reflects the growing inner Indian anxiety on China's presence in India's neighbouring countries. Therefore, the biggest challenge for Bangladesh is to maintain a careful balancing act between cultivating economic ties with China and maintaining good relations with India at the regional level. While giving an interview to Indian journalists recently at her office in Dhaka, Prime Minister Sheikh Hasina said that Indian leadership in New Delhi "should not be worried" about Bangladesh's growing ties with China. Thus, such bold statement by the prime minister reflects Dhaka's cooperation with 


\section{ELK ASIA PACIFIC JOURNAL OF SOCIAL SCIENCE}

ISSN 2394-9392 (Online); DOI: 10.16962/EAPJSS/issn. 2394-9392/2015; Volume 5 Issue 1 (2018)

Beijing is meant only to foster

infrastructural development in her country.

In this changing international scenario, the centre of global economic and political gravity has been shifting to the Asia pacific region. Therefore, for the first time after its liberation, Bangladesh has got the opportunity to make the best use of its geostrategic significance by cooperating with both the Asian powers, India and China, in order to foster infrastructural development, thus to facilitate economic growth (Zaman, 2017). Bangladesh is the land bridge between the developing South and semi-industrialized South East Asia, and it is also very close to the virtually landlocked provinces of south-western China as well. Moreover, the country has access to the Indian Ocean through the Bay of Bengal. This unique geographical location of Bangladesh has given it a role in stabilizing this critical area through linking these various regions together. Thus, Bangladesh can be the economic hub of this area by developing deep-sea port, greater rail, road and river connectivity. Moreover, the country can offer huge skilled and semi-skilled workforce ready to be employed in the manufacturing industries.
India needs land corridor through Bangladesh to facilitate economic development in its northeastern provinces. Moreover, Bangladesh is an important country to materialize India's "Act East" policy Without $\mathrm{s}$ strong land-based connectivity with neighbouring Bangladesh it is not possible for India to develop regional connectivity with South East Asian countries (Masood, 2015). Thus, Bangladesh can use the existing Indo-Bangladesh relationship as a catalyst to intensify regional and sub-regional integration between Bangladesh, Bhutan, Nepal and North-East India under the aegis Bangladesh, Bhutan, India, Nepal (BBIN) initiative and Bay of Bengal Initiative for Multi-Sectoral Technical and Economic Cooperation (BIMSTEC). These regional and sub-regional initiatives will help Bangladesh to expand its market to India's northeastern states, Bhutan, and Nepal. At the same time, Bangladesh can provide sea-port facilities within the BBIN subregional initiative. Nevertheless, Nepal and Bhutan have enormous hydroelectric potential that could benefit the energy deficient Bangladesh as well. 


\section{ELK ASIA PACIFIC JOURNAL OF SOCIAL SCIENCE}

ISSN 2394-9392 (Online); DOI: 10.16962/EAPJSS/issn. 2394-9392/2015; Volume 5 Issue 1 (2018)

Bangladesh is located at the middle of the BCIM Economic Corridor, an economic region within the China-led OBOR initiative. Moreover, the country has a maritime strategic position as the Chittagong port is a major pivot through the Indian Ocean. Thus, China needs Bangladesh onboard to activate both the Silk Road Economic Belt and the 21st Century Maritime Silk Road (Nahreen, 2017). Therefore, Bangladesh has the potential to leverage its geostrategic significance through this OBOR initiative.

The Chinese economy is transforming at a rapid pace towards a developed economy. China has been moving away from lowtech industries to towards high margin and high-tech industries like IT, aerospace, and artificial intelligence. Moreover, labour cost is also on the rise in China. Thus, China companies have been trying to relocate their surplus industrial capacities to places with cheap labour. A huge skilled and semi-skilled workforce at one of the cheapest rates in the world, coupled with its advantageous geographic location, thus makes Bangladesh a suitable option to host the relocated Chinese manufacturing industries (Nahreen,2017). However, Bangladesh needs to ensure good governance, transparency, sound bureaucracy, and a well-functioning financial system to absorb such large-scale investments. Moreover, Bangladeshi policymakers need to be careful about avoiding any long-term debt crisis which might harm the country's macroeconomic stability (Saimum,2017).

Experts have raised concern that the ongoing Sino-Indian rivalry can jeopardize Bangladesh's prospects in the OBOR. A proposed corridor within the OBOR, China Pakistan Economic Corridor (CPEC), goes through Pakistan administered Kashmir, a disputed territory between India and Pakistan. As a result, India has kept itself out of OBOR on the ground of sovereignty. India, along with Japan, has expressed its intention to counter OBOR ("India and Japan to counter OBOR",2017). Given India's inbuilt influence in South Asia, it can halt the progress of OBOR related projects in the region. Therefore, without India's involvement, it will be difficult for Bangladesh to make the best use of OBOR (Saimum, 2017). Thus, Bangladesh needs to reap the full benefits of China's mega project within the given geopolitical compulsion under which it has to operate. 


\section{ELK ASIA PACIFIC JOURNAL OF SOCIAL SCIENCE}

ISSN 2394-9392 (Online); DOI: 10.16962/EAPJSS/issn. 2394-9392/2015; Volume 5 Issue 1 (2018)

According to Ballard (2018):

$$
\begin{aligned}
& \text { As regional ties become } \\
& \text { closer and more } \\
& \text { complicated, it is essential } \\
& \text { that Bangladesh preserves } \\
& \text { its own interests. } \\
& \text { Cooperation with the } \\
& \text { region's major powers } \\
& \text { could accelerate the } \\
& \text { country's upward } \\
& \text { progression, but Dhaka } \\
& \text { should be wary of undue } \\
& \text { influence from more } \\
& \text { powerful neighbours. As } \\
& \text { the power struggle } \\
& \text { between India and China } \\
& \text { develops, Bangladesh } \\
& \text { should ensure that its own } \\
& \text { sovereignty and economic } \\
& \text { development does not } \\
& \text { come under threat. } \\
& \text { Investment from the two } \\
& \text { countries should be } \\
& \text { welcomed, but not at any } \\
& \text { cost. }
\end{aligned}
$$

Nevertheless, Bangladesh should not totally downgrade its existing strategic partnership with the United States. The
Trump administration has already declared its intention to focus on the Indo-Pacific region including to expand economic connectivity, alliances and partnership. As a being a country within the Indo-Pacific region, Bangladesh can further expand bilateral trade and maritime cooperation with the United States as a part of the latter's New Asia Policy (Bari, 2018).

The Eleventh National Parliamentary Elections of Bangladesh is expected to take place in December 2018. The postelections political landscape of Bangladesh will further determine the role of regional powers like India and China inside the country.

\section{CONCLUDING STATEMENT}

China and India's robust economic growth have been impacting on the global balance of power and the international system. The countries those are proximate to both China and India are increasingly becoming potential places for geostrategic competition between them. Both India and China, with dynamic economies, have been trying to expand their regional and global influence. In the regional equation, Bangladesh should play a constructive to 


\section{ELK ASIA PACIFIC JOURNAL OF SOCIAL SCIENCE}

ISSN 2394-9392 (Online); DOI: 10.16962/EAPJSS/issn. 2394-9392/2015; Volume 5 Issue 1 (2018)

activate the proposed regional and subregional economic initiatives to foster connectivity and thus facilitate economic growth. Bangladesh needs to work closely with India to maintain regional peace and stability in the first instance. The two countries should cooperate to resolve the geography-driven disputes (e.g. sharing of transboundary river water) and pursue for a future based on mutual benefit. At the same time, Bangladesh needs to maintain sound bilateral relations with China for trade and technological assistance. Dhaka needs to ensure New Delhi that a Bangladesh's cooperation with China will not create any strategic threat for India. Bangladesh should properly utilize the economic opportunities provided by the ongoing geostrategic competition between India and China. The primary concern for Bangladesh is the potential for a psychical conflict between the two sides. Thus, Dhaka should remain neutral regarding any disputed issue between New Delhi and Beijing in the upcoming years. The peaceful rise of both India and China will be beneficial for Bangladesh. Therefore, Bangladesh can play an important role in engaging both countries through promoting trans-regional connectivity.

\section{REFERENCES}

Andersen, W. (2012, March). The Geostrategic Importance of Bangladesh: From the Perspective of the US. Vibrant Bangladesh. (5), pp. 72-77. Retrieved from http://www.bdembassyusa.org/uplo ads/Vibrant\%20Bangladesh_26\%2 0March_2012.pdf

Ballard, B. (2018, March 6). China vs India: the battle for supremacy. World Finance. Retrieved from https://www.worldfinance.com/stra tegy/china-vs-india-the-battle-forsupremacy

Bangladesh Bank allows forex clearing account in Chinese yuan. (2018, August 15). New Age. Retrieved from http://www.newagebd.net/article/48 452/bangladesh-bank-allows-forexclearing-account-in-chinese-yuan

Bangladesh boycotts SAARC summit in Islamabad amid India-Pakistan row. (2016, September, 27). BDnews24. Retrieved from https://bdnews24.com/bangladesh/2 016/09/27/bangladesh-boycotts- 


\section{ELK ASIA PACIFIC JOURNAL OF SOCIAL SCIENCE}

ISSN 2394-9392 (Online); DOI: 10.16962/EAPJSS/issn. 2394-9392/2015; Volume 5 Issue 1 (2018)

saarc-summit-in-islamabad-amid-

india-pakistan-row

Bari, L. F. (2018, January 31). US eager to work with Indo-Pacific region. Dhaka Tribune. Retrieved from

https://www.dhakatribune.com/ban gladesh/foreign-

affairs/2018/01/31/us-eager-workindo-pacific-region

Brzezinski, Z. (1986). Game Plan: A Geostrategic Framework for the Conduct of the U.S.-Soviet Contest. Boston: The Atlantic Monthly Press.

Chinese company to construct Padma bridge. (2014, May 19). BDnews24. Retrieved from https://bdnews24.com/economy/20 14/05/19/chinese-company-toconstruct-padma-bridge

'China to be top investor in Bangladesh'. (2016, October 4). Dhaka Tribune. Retrieved from https://www.dhakatribune.com/busi ness/2016/10/04/china-topinvestor-bangladesh

China visit to deepen relation: PM. (2014, June 14). Prothom Alo English.
Retrieved from https://en.prothomalo.com/banglad esh/news/49008/China-visit-todeepen-relation-PM

Cookson, F., \& Joehnk, T. F. (2018, April 11). China and India's geopolitical tug of war for Bangladesh. East Asia Forum. Retrieved from http://www.eastasiaforum.org/2018 /04/11/china-and-indiasgeopolitical-tug-of-war-forbangladesh/

Datta, S. (2008). Bangladesh's Relations with China and India: A Comparative Study. Strategic Analysis, 32(5), 755-772. doi: 10.1080/09700160802309134

Defense Cooperation: Dhaka, Delhi sign deal. (2018, May 12). The Daily Star. Retrieved from https://www.thedailystar.net/backp age/dhaka-delhi-sign-3-deals1575109

Eaton, R. M. (1996). The Rise of Islam and the Bengal Frontier, 1204-1760. University of California Press.

Grygiel, J. J. (2006). Great Powers and Geopolitical Change. Baltimore: 


\section{ELK ASIA PACIFIC JOURNAL OF SOCIAL SCIENCE}

ISSN 2394-9392 (Online); DOI: 10.16962/EAPJSS/issn. 2394-9392/2015; Volume 5 Issue 1 (2018)

The Johns Hopkins University

Business Line. Retrieved from Press.

Hossain, M. (2016, November 10). How

huge China investment

in Bangladesh affects region.

Anadolu Agency, Retrieved

from

https://www.aa.com.tr/en/analysis-

news/opinion-how-huge-china-

investment-in-bangladesh-affects-

region/683065

Imam, S. H. (2017, December 1).

Closer China-Bangladesh ties shouldn't worry India. The

Daily Star. Retrieved

from

https://www.thedailystar.net/opinio

n/pleasure-all-mine/closer-china-

bangladesh-ties-shouldnt-worry-

india-1498687

Indian businesses to invest $\$ 9$ billion in Bangladesh. (2017, April 9).

BDnews24. Retrieved from

https://bdnews24.com/business/201

7/04/09/indian-businesses-to-

invest-9-billion-in-bangladesh

India's exports to Bangladesh bounce back, record $13 \%$ growth in FY17. (2017, October 22). The Hindu 


\section{ELK ASIA PACIFIC JOURNAL OF SOCIAL SCIENCE}

ISSN 2394-9392 (Online); DOI: 10.16962/EAPJSS/issn. 2394-9392/2015; Volume 5 Issue 1 (2018)

om/economy/indias-exports-to-

bangladesh-bounce-back-record-

13-growth-in-

fy17/article9918488.ece

India extends $\$ 4.5$ billion loan to

Bangladesh. (2017, October 05).

Mint. $\quad$ Retrieved from

https://www.livemint.com/Politics/

PJNGy9mN1sOLFqVTKKdI5L/Ba

ngladesh-signs-45-billion-loan-

deal-with-India.html

India plans to invest $\$ 3 b$ in Bangladesh.

(2017, February 17). The Daily

Star. Retrieved from

https://www.thedailystar.net/busine

ss/india-plans-invest-3b-

bangladesh-1362328

India shouldn't worry about China-

Bangladesh ties, says Sheikh

Hasina. (2018, February 21).

NDTV. Retrieved

from https://www.ndtv.com/india-

news/india-shouldnt-worry-about-

china-bangladesh-ties-says-prime-

minister-sheikh-hasina-1815352

Jiemian, Y. (2014, February 22). From geostrategy to omnistrategy: interactions among China, Europe and the United States. Shanghai 


\section{ELK ASIA PACIFIC JOURNAL OF SOCIAL SCIENCE}

ISSN 2394-9392 (Online); DOI: 10.16962/EAPJSS/issn. 2394-9392/2015; Volume 5 Issue 1 (2018)

Institute for International Studies.

Business Today. Retrieved from

Retrieved

from

https://www.mmbiztoday.com/artic

http://en.siis.org.cn/Research/EnInf

$\mathrm{o} / 2051$

Kabir, A. (2018, May 16). China

outbids India for Bangladesh's

largest stock exchange - What's

next? Forbes. Retrieved

from

https://www.forbes.com/sites/arafat

kabir/2018/05/16/china-outbids-

india-for-bangladeshs-largest-

stock-exchange-whats-

next/\#4ae17c617f2c

Mahmud, N. (2018, August 20).

Personal interview.

Mantoo. S. A. (2013). India and the Strategic importance of Bangladesh. Peace and Security Review. 5 (9), pp. 46-57. Retrieved from

https://www.scribd.com/document/ 256721860/INDIA-AND-THESTRATEGIC-IMPORTANCE-OFBANGLADESH

Masood, A. (2015, March 30). IndiaBangladesh-China Relations: A Complex Triangle. Myanmar 


\section{ELK ASIA PACIFIC JOURNAL OF SOCIAL SCIENCE}

ISSN 2394-9392 (Online); DOI: 10.16962/EAPJSS/issn. 2394-9392/2015; Volume 5 Issue 1 (2018)

les/india-bangladesh-china-

relations-complex-triangle

Nahreen, A. (2017, April 21). The growing strategic importance of Bangladesh to China. The Daily Star. Retrieved from

https://www.thedailystar.net/oped/the-growing-strategicimportance-bangladesh-china1393957

Pant, H. V. (2018, January 16). Sino- Indian jostling in South Asia. Yale Global Online. Retrieved from https://yaleglobal.yale.edu/content/ sino-indian-jostling-south-asia

Rahman, M. S. (2016). Bangladesh and its neighbors. In A. Riaz, \& M. S. Rahman (Eds.), Routledge Handbook of Contemporary Bangladesh (1st ed., pp. 378-388). New York, NY: Routledge.

Rashid, H. (2011, April 27). Barriers hamper exports to India. The Daily Star. Retrieved from https://www.thedailystar.net/newsdetail-183285

Saimum, R. (2017, November 1). What One Belt One Road means for 


\section{ELK ASIA PACIFIC JOURNAL OF SOCIAL SCIENCE}

ISSN 2394-9392 (Online); DOI: 10.16962/EAPJSS/issn. 2394-9392/2015; Volume 5 Issue 1 (2018)

Bangladesh. Dhaka Tribune. https://www.worldpoliticsreview.co

Retrieved from $\mathrm{m} /$ trend-lines/24630/why-india-

https://www.dhakatribune.com/opi

nion/op-ed/2017/10/31/one-belt-

one-road-means-bangladesh/

Schmidt, J. D. (2011, April). India China Rivalry and Competition in Southeast Asia. Paper presented at India in International Relations: European and Indian perspectives, New Delhi.

To counter OBOR, India and

Japan propose Asia-Africa sea corridor. (2017, May 31). The Indian Express. Retrieved from https://indianexpress.com/article/ex plained/to-counter-obor-india-andjapan-propose-asia-africa-seacorridor-4681749/

Wagner, C. (2016). The Role of India and China in South Asia. Strategic Analysis, 40(4), pp. 307-320. doi: 10.1080/09700161.2016.1184790

Why India and China Are Competing for Better Ties with Bangladesh. (2018, April 26). World Politics Review. Retrieved from 


\section{ELK ASIA PACIFIC JOURNAL OF SOCIAL SCIENCE}

ISSN 2394-9392 (Online); DOI: 10.16962/EAPJSS/issn. 2394-9392/2015; Volume 5 Issue 1 (2018) and-china-are-competing-forbetter-ties-with-bangladesh

Yasmin, L. (2016). Bangladesh and the great powers. In A. Riaz, \& M. S. Rahman (Eds.), Routledge Handbook of Contemporary Bangladesh (1st ed., pp. 389-401). New York, NY: Routledge.

Yusuf, A. A. (2014, March 10). Geostrategic significance: A nontraditional perspective. The Daily Star. $\quad$ Retrieved from https://www.thedailystar.net/geostrategic-significance-a-nontraditional-perspective-14836

Zaman, R. U. (2017, September 1). Can Bangladesh turn its burdensome geography into a blessing? East Asia Forum. Retrieved from http://www.eastasiaforum.org/2017 /09/01/can-bangladesh-turn-itsburdensome-geography-into-ablessing/ 